Myrtaj Nazim, Shkodra Mimoza, Bilalli Eglantina, Maliqi Arben, Sylejmani Blerim. The impact of the educational level of the family on the lifestyle of children before and during the COVID-19 pandemic. Journal of Education, Health and Sport. 2021;11(6):155-163. eISSN 2391-8306. DOI http://dx.doi.org/10.12775/JEHS.2021.11.06.016

https://apcz.umk.pl/czasopisma/index.php/JEHS/article/view/JEHS.2021.11.06.016

https://zenodo.org/record/5037195

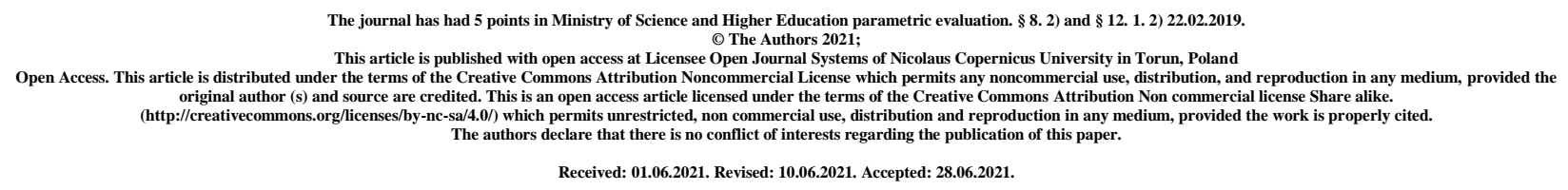

\title{
The impact of the educational level of the family on the lifestyle of children before and during the COVID-19 pandemic
}

\author{
Nazim Myrtaj ${ }^{1}$, Mimoza Shkodra ${ }^{1}$, Eglantina Bilalli ${ }^{2}$, Arben Maliqi ${ }^{1}$, Blerim Sylejmani $^{1}$ \\ ${ }^{1}$ Faculty of Physical Culture and Sports, AAB College, Prishtina, KOSOVO \\ ${ }^{2}$ Independent Researcher
}

Corresponding Author: MIMOZA SHKODRA, E-mail: mimoza.shkodra@aab-edu.net

\begin{abstract}
The lifestyle of children is most affected by the family, which is defined as a basic social community based on the common life of a close circle of blood relatives, usually parents and children, in which biological-reproductive, economic and education functions are combined. The purpose of the research is to confirm the impact of the educational level of parents on the lifestyle of their children before and during the COVID-19 pandemic. The research included 110 students of both genders from SHMT "Mehmet Isai" and SHMAT "Arbëria" in Gjilan divided into two groups of 55 students, according to the educational level of their parents. The lifestyle survey included 8 questions on physical activity, daily cigarette consumption, alcohol, drug use, eating habits and sleep before and during COVID -19 pandemic.

To verify the difference between the groups, the Chi-square test ( $\chi^{2}$ test) was applied. Survey analysis shows that children of parents with higher educational level have more knowledge about the role of physical activity and spend more time on physical activity, consume less cigarettes and alcohol and more regular eating and sleeping habits at the level $p<0.00$. We can conclude that the educational level of the parents has a significant impact on the motivation of children to engage in physical activity, reducing the consumption of cigarettes and alcohol, for sleep and regular nutrition.
\end{abstract}


Key words: Physical activity, survey, family, COVID-19 pandemic, Chi-square test

\section{Introduction}

Lifestyle is the expression of situations, life experiences, values, feelings and expectations. Lifestyle influences needs and habits and can be defined as the way of life, the way people live, how people spend time (activities), what they consider important in the environment (interests), what they think about themselves (thoughts). We can say that lifestyle is a form of self-satisfaction, it shows who we are and what we should be, i.e., it seems like a new set of norms and rules of conduct in the wave of traditional norms and values of behavior. Living components and their interaction are inevitably complex (Klarin, 2006).

Generally, it is known that even before that the recreational activity was used for prevention and rehabilitation of disease but infectious diseases also. Nowadays, people's habits for physical exercises and recreational activities have disappeared, but also the way of life and active work has been reduced to a minimum. All of this caused a decline in the function of organs and organ systems, leading to a new disease called inactivity in motion or immobility. By this type of activity we mean daily activity (Kopko, 2007).

Parents can influence their children in shaping attitudes and behaviors when it comes to lifestyle and physical activities from not knowing the health consequences and psychosocial effects of the COVID-19 pandemic, therefore, the content of these tips is a start great in this regard. Throughout life, the child should be encouraged to be active for at least one hour a day through activities ranging from natural movement activities, active games to organized sports. Some forms of physical activity are more appropriate for younger children, and some for adolescents. Younger children usually strengthen their muscles through natural movements as a precaution against the functional bodily deformities (Raboteg-Šarić, Sakoman, Brajša-Žganec, 2002).

The family is the basis of the functioning of any system. The overall personality development of a child is largely conditioned by the influence of the family. Primary influence refers mainly to the educational actions of the parents. The phenomenon of parenting is a complex, extensive and continuous process that is significantly conditioned by the characteristics of different stages of the family life cycle, where parents are expected to adjust their educational activities to the specifics of each stage (Milutinović, Zuković, Klemenović, 2012). This is why we can say that raising a child is primarily a psychological-emotional behavioral ability and parents have an extremely complex role. Except for the extremes which are made by very strict and extremely gentle parents, where there is no perfect parent, there is an environment represented by mothers and fathers who provide their children with a lot of love, support by giving clear instructions and setting clear boundaries - consistent, supportive parents. The purpose of the research is to verify the impact of parents' educational level on the lifestyle of their children and to verify the impact of the COVID-19 pandemic period on the lifestyle of children. 


\section{Methods}

The research included 110 male students aged $18 \pm 6$ from "Mehmet Isai" hight school and "Arbëria" hight school in Gjilan divided in two groups of 55 students, according to the educational level of their parents, parents with high education and low education education. The lifestyle survey included 8 questions on physical activity, daily consumption of cigarettes, alcohol, drugs, eating and sleeping habits before and during the COVID-19 pandemic. The questionnaire for the purposes of this paper has been modified according to the needs of this paper (Robertson, Lobstein, Knai, (2007). The survey questions were: 1) I deal with recreational sports activities, 2) Is the organization of sports and recreational sports activities beneficial to your health, 3) Do you actively participate in any sports activity, 4) How many cigarettes do you consume per day, 5) Do you consume alcohol, 6) Do you use drugs, 7) Habits in food and meals, 8) How many hours of sleep do you get in 24 hours. The processing of the results was performed by non-parametric technique, by means of Chi-square test.

\section{Results}

In the respondents' question "I do recreational sports activities", there is a statistically significant difference within the groups between the respondents whose parents are with higher education and those with lower education at the level $(\mathrm{P}<0.01)$. Students whose parents have higher education are more involved in recreational sports activities. In the two groups of students divided according to the level of education of their parents, there is a statistically significant difference in the level $(\mathrm{P}<0.01)$ between the period before COVID-19 and during the period COVID-19. During the COVID-19 period we have less recreational sports activities in both groups (Table 1).

Table 1. Question: "I deal with recreational sports activities"

\begin{tabular}{|l|c|c|c|c|c|c|c|c|c|}
\hline & Superior & Low & $\sum$ & Superior & C-19 & $\sum$ & Low & C-19 & $\sum$ \\
\hline 1. & 16 & 9 & 25 & 16 & 11 & 27 & 9 & 4 & 25 \\
\hline 2 & 33 & 27 & 60 & 33 & 21 & 54 & 27 & 16 & 43 \\
\hline 3 & 6 & 19 & 25 & 6 & 23 & 29 & 19 & 35 & 54 \\
\hline$\sum$ & 55 & 55 & 110 & 55 & 55 & 110 & 55 & 55 & 110 \\
\hline$\chi^{2}$ & $\mathrm{P}<0.000$ & $\mathrm{P}<0.011$ & $\mathrm{P}<0.011$ & $\mathrm{P}<0.000$ & $\mathrm{P}>0.104$ & $\mathrm{P}<0.003$ & $\mathrm{P}<0.011$ & $\mathrm{P}<0.000$ & $\mathrm{P}<0.021$ \\
\hline
\end{tabular}

Legend: 1-Regularly (at least 3 times a week), 2-Occasionally (mostly weekends), 3-Never, C19-COVID19, Superior-Superior Education, Low -Lower Education, $\chi 2$ - Chi- square test.

In the respondents' question "Organizing sports and recreational sports activities will be useful", there is a statistically significant difference within the groups as well as between the surveyed groups whose parents are with higher education and those with lower education in level ( $\mathrm{P}<0.01)$. Students whose parents are with higher education think more that organizing sports and recreational sports activities will be beneficial. In the group of respondents whose parents are with higher education we did not gain a statistically significant difference at the level (P> 0.93)bbetween the period before COVID-19 and during the period COVID-19. 
In the group of respondents whose parents are with low education we gained a statistically significant difference in the level $(\mathrm{P}<0.01)$ between the period before COVID-19 and during the period COVID-19, because most of the respondents during the period COVID -19 think that the organization of sports and recreational sports activities will be useful (Table 2).

Table 2. Question: "Organizing sports and recreational sports activities will be useful"

\begin{tabular}{|l|c|c|c|c|c|c|c|c|c|}
\hline & Superior & Low & $\sum$ & Superior & C-19 & $\sum$ & Low & C-19 & $\sum$ \\
\hline 1. & 47 & 31 & 78 & 47 & 50 & 97 & 31 & 48 & 79 \\
\hline 2 & 6 & 14 & 20 & 6 & 4 & 10 & 14 & 3 & 17 \\
\hline 3 & 2 & 10 & 12 & 2 & 1 & 3 & 10 & 4 & 14 \\
\hline$\sum$ & 55 & 55 & 110 & 55 & 55 & 110 & 55 & 55 & 110 \\
\hline$\chi^{2}$ & $\mathrm{P}<0.000$ & $\mathrm{P}<0.001$ & $\mathrm{P}<0.009$ & $\mathrm{P}<0.000$ & $\mathrm{P}<0.104$ & $\mathrm{P}>0.931$ & $\mathrm{P}<0.001$ & $\mathrm{P}<0.000$ & $\mathrm{P}<0.004$ \\
\hline
\end{tabular}

Legend: 1-Yes, 2- Not sure, 3-No, C19-COVID-19, Superior-Superior Education, Low -Low Education, $\chi 2$ - Chi-square test.

In the respondents' question "Do you actively participate in any sports activity", there is a statistically significant difference within the group of respondents whose parents have higher education level $(\mathrm{P}<0.01)$ and not within the group of parents who are with low education level (P> 0.51). Students whose parents are with higher education are more actively involved in any sports activity. In the two groups of students divided according to their parents' level of education, there is a statistically significant difference in the level $(\mathrm{P}<0.01)$ between the period before COVID-19 and during the period COVID-19. During the COVID-19 period we have less recreational sports activities in both groups (Table 3 ).

Table 3. Question: "Do you actively participate in any sports activity"

\begin{tabular}{|l|c|c|c|c|c|c|c|c|c|}
\hline & Superior & Low & $\sum$ & Superior & C-19 & $\sum$ & Low & C-19 & $\sum$ \\
\hline 1. & 36 & 22 & 58 & 36 & 10 & 46 & 22 & 3 & 25 \\
\hline 2 & 11 & 18 & 20 & 11 & 15 & 26 & 18 & 9 & 27 \\
\hline 3 & 8 & 15 & 22 & 8 & 30 & 38 & 15 & 43 & 58 \\
\hline$\sum$ & 55 & 55 & 110 & 55 & 55 & 110 & 55 & 55 & 110 \\
\hline$\chi^{2}$ & $\mathrm{P}<0.000$ & $\mathrm{P}>0.510$ & $\mathrm{P}>0.057$ & $\mathrm{P}<0.000$ & $\mathrm{P}<0.003$ & $\mathrm{P}<0.000$ & $\mathrm{P}>0.510$ & $\mathrm{P}<0.000$ & $\mathrm{P}<0.000$ \\
\hline
\end{tabular}

Legend: 1-Yes, 2- Once, 3-No, C19-COVID-19, Superior-Superior Education, Low -Low Education, $\chi 2$ -

Chi-square test. 
In the respondents' question "Frequency of cigarette consumption, daily consumption", there is a statistically significant difference within the groups as well as between the respondent groups whose parents are with higher education and those with lower education at the level $(\mathrm{P}<$ 0.05). In the group of respondents whose parents are with higher education, we did not gain a statistically significant difference between the period before COVID-19 and during the period COVID-19 at the level (P> 0.93) in the daily consumption of cigarettes. In the group of respondents whose parents are with low education, we gained a statistically significant difference in the level $(\mathrm{P}<0.01)$ between the period before COVID-19 and during the period COVID-19 in the daily consumption of cigarettes. Here it is evidenced that most respondents during the COVID-19 period have reduced their daily cigarette consumption (Table 4).

Table 4. Question: "Frequency of cigarette consumption, daily consumption"

\begin{tabular}{|l|c|c|c|c|c|c|c|c|c|}
\hline & Superior & Low & $\sum$ & Superior & C-19 & $\sum$ & Low & C-19 & $\sum$ \\
\hline 1. & 25 & 36 & 60 & 24 & 18 & 42 & 36 & 27 & 63 \\
\hline 2 & 6 & 9 & 15 & 6 & 4 & 10 & 9 & 3 & 12 \\
\hline 3 & 24 & 10 & 35 & 25 & 33 & 58 & 10 & 25 & 35 \\
\hline$\sum$ & 55 & 55 & 110 & 55 & 55 & 110 & 55 & 55 & 110 \\
\hline$\chi^{2}$ & $\mathrm{P}<0.002$ & $\mathrm{P}<0.000$ & $\mathrm{P}<0.019$ & $\mathrm{P}<0.002$ & $\mathrm{P}<0.000$ & $\mathrm{P}>0.463$ & $\mathrm{P}<0.000$ & $\mathrm{P}<0.000$ & $\mathrm{P}<0.013$ \\
\hline
\end{tabular}

Legend: 1-10 to 20 cigarettes, 2- More than 20 cigarettes per day, 3-I do not consume, C19-COVID-19, Superior-Superior Education, Low-Lower Education, $\chi 2$ - Chi-square test.

In the respondents' question "Frequency of alcohol consumption, daily consumption", there is a statistically significant difference within the groups at the level of $\mathrm{P}<0.01$ ) but not between the groups of respondents whose parents are with higher education and those with low level education ( $\mathrm{P}>0.168$ ). Most respondents do not consume alcohol. In both groups of students divided according to the level of education of their parents, there is a statistically significant difference in level $(\mathrm{P}<0.01)$ between the period before COVID-19 and during the period COVID-19. During the COVID-19 period most of the respondents have increased alcohol consumption (Table 5).

Table 5. Question: "Frequency of alcohol consumption, daily consumption"

\begin{tabular}{|l|c|c|c|c|c|c|c|c|c|}
\hline & Superior & Low & $\sum$ & Superior & C-19 & $\sum$ & Low & C-19 & $\sum$ \\
\hline 1. & 5 & 7 & 12 & 5 & 18 & 23 & 7 & 27 & 34 \\
\hline 2 & 12 & 21 & 33 & 12 & 4 & 16 & 21 & 3 & 24 \\
\hline 3 & 38 & 27 & 65 & 38 & 33 & 71 & 27 & 25 & 55 \\
\hline$\sum$ & 55 & 55 & 110 & 55 & 55 & 110 & 55 & 55 & 110 \\
\hline$\chi^{2}$ & $\mathrm{P}<0.000$ & $\mathrm{P}<0.003$ & $\mathrm{P}>0.168$ & $\mathrm{P}<0.000$ & $\mathrm{P}<0.000$ & $\mathrm{P}<0.008$ & $\mathrm{P}<0.003$ & $\mathrm{P}<0.000$ & $\mathrm{P}<0.000$ \\
\hline
\end{tabular}

Legend: 1- Regularly (every day), 2- from time to time (sometimes a week), 3- I do not consume it, C19COVID-19, Superior-Superior Education, Low-Lower Education, $\chi 2$ - Chi-square test. 
In the respondents' question "Do you consume drugs", there is a statistically significant difference within the groups at the level $(\mathrm{P}<0.01)$ but not between the groups of respondents whose parents are with higher education and those with lower education in level ( $\mathrm{P}>0.652)$. Most respondents do not consume drugs. In the two groups of students divided according to the level of education of their parents, there is a statistically significant difference in level $(\mathrm{P}<0.01)$ between the period before COVID-19 and during the period COVID-19 . During the COVID-19 period most respondents had lower drug consumption (Table 6).

Table 6. Question: "Do you consume drugs"

\begin{tabular}{|l|c|c|c|c|c|c|c|c|c|}
\hline & Superior & Low & $\sum$ & Superior & C-19 & $\sum$ & Low & C-19 & $\sum$ \\
\hline 1. & 2 & 3 & 12 & 2 & 2 & 4 & 3 & 3 & 6 \\
\hline 2 & 13 & 18 & 33 & 13 & 0 & 13 & 18 & 1 & 19 \\
\hline 3 & 40 & 34 & 65 & 40 & 53 & 93 & 34 & 51 & 85 \\
\hline$\sum$ & 55 & 55 & 110 & 55 & 55 & 110 & 55 & 55 & 110 \\
\hline$\chi^{2}$ & $\mathrm{P}<0.000$ & $\mathrm{P}<0.000$ & $\mathrm{P}>0.652$ & $\mathrm{P}<0.000$ & $\mathrm{P}<0.000$ & $\mathrm{P}<0.002$ & $\mathrm{P}<0.000$ & $\mathrm{P}<0.000$ & $\mathrm{P}<0.000$ \\
\hline
\end{tabular}

Legend: 1- Regularly (every day), 2- I have tried it once, 3-I do not consume it, C19-COVID-19,

Superior-Superior education, Low-Low education, $\chi 2$ - Chi-square test.

In the respondents' question "Habits in food and meals", there is a statistically significant difference at the level $(\mathrm{P}<0.05)$ within the groups as well as between the surveyed groups whose parents are with higher education and those with lower education. In the group of respondents whose parents are with higher education at the level $(\mathrm{P}>0.25)$, we did not gain a statistically significant difference between the period before COVID-19 and during the period COVID-19 in the habits in food and meals. In the group of respondents whose parents are with low education we also did not gain a statistically significant difference in the level $(\mathrm{P}>0.11)$ between the period before COVID-19 and during the period COVID-19 in the habits in food and meals ( Table 7).

Table 7. Question: "Habits in food and meals"

\begin{tabular}{|l|c|c|c|c|c|c|c|c|c|}
\hline & Superior & Low & $\sum$ & Superior & C-19 & $\sum$ & Low & C-19 & $\sum$ \\
\hline 1. & 0 & 2 & 2 & 0 & 0 & 0 & 2 & 0 & 2 \\
\hline 2 & 21 & 31 & 52 & 21 & 16 & 37 & 31 & 19 & 50 \\
\hline 3 & 33 & 17 & 50 & 33 & 33 & 66 & 17 & 30 & 57 \\
\hline 4 & 1 & 5 & 6 & 1 & 6 & 7 & 5 & 6 & 11 \\
\hline$\sum$ & 55 & 55 & 110 & 55 & 55 & 110 & 55 & 55 & 110 \\
\hline$\chi^{2}$ & $\mathrm{P}<0.000$ & $\mathrm{P}<0.000$ & $\mathrm{P}<0.044$ & $\mathrm{P}<0.000$ & $\mathrm{P}<0.000$ & $\mathrm{P}>0.254$ & $\mathrm{P}<0.000$ & $\mathrm{P}<0.000$ & $\mathrm{P}>0.112$ \\
\hline
\end{tabular}

Legend: 1- 1 time per day, 2- 2 times per day, 3-3 times per day, 4-4 times per day, C19-COVID-19, Superior-Superior Education, Low-Lower Education, $\chi 2$ - Chi -square test. 
In the question of the respondents "How many hours of sleep do you get in 24 hours", there is a statistically significant difference in the level $(\mathrm{P}<0.05)$ within the groups as well as between the surveyed groups whose parents are with higher education and those with lower education. In the group of respondents whose parents are with higher education, we gained a statistically significant difference in the level $(\mathrm{P}<0.01)$ between the period before COVID-19 and during the period COVID-19 in the habit regarding question; how many hours of sleep do you do in 24 hours. In the group of respondents whose parents are with low education we did not gain a statistically significant difference in the level $(\mathrm{P}>0.11)$ between the period before COVID-19 and during the period COVID-19 in habit regarding question; how many hours of sleep in 24 hours (Table 8).

Table 8. Question: "How many hours of sleep do you get in 24 hours"

\begin{tabular}{|l|c|c|c|c|c|c|c|c|c|}
\hline & Superior & Low & $\sum$ & Superior & C-19 & $\sum$ & Low & C-19 & $\sum$ \\
\hline 1. & 2 & 0 & 2 & 2 & 0 & 2 & 0 & 0 & 0 \\
\hline 2 & 7 & 3 & 10 & 7 & 1 & 8 & 3 & 1 & 4 \\
\hline 3 & 11 & 9 & 20 & 11 & 6 & 17 & 9 & 7 & 16 \\
\hline 4 & 28 & 18 & 46 & 28 & 21 & 49 & 18 & 15 & 33 \\
\hline 5 & 3 & 15 & 18 & 3 & 19 & 22 & 15 & 23 & 38 \\
\hline 6 & 4 & 10 & 14 & 4 & 8 & 12 & 10 & 9 & 19 \\
\hline$\sum$ & 55 & 55 & 110 & 55 & 55 & 110 & 55 & 55 & 110 \\
\hline$\chi^{2}$ & $\mathrm{P}<0.000$ & $\mathrm{P}<0.000$ & $\mathrm{P}>0.039$ & $\mathrm{P}<0.000$ & $\mathrm{P}<0.000$ & $\mathrm{P}<0.006$ & $\mathrm{P}<0.000$ & $\mathrm{P}<0.000$ & $\mathrm{P}>0.786$ \\
\hline
\end{tabular}

Legend: 1-5 hours, 2-6 hours, 3-7 hours, 4-8 hours, 5-9 hours, 6-9 hours, C19-COVID-19, SuperiorSuperior Education, Low-Lower Education, $\chi 2$ - Chi-square test.

\section{Discussion}

Findings from the obtained data showed that quarantine at home by the COVID-19 pandemic had a negative effect on the lifestyle of young people, this shows how important is the educational level of parents in child's education, in their lifestyle, in mental well-being, emotional status, psychosocial support. Therefore, to have an understanding of these suggestions provided through scientific evidence, the current survey also focused on changes in youth lifestyle behaviors before and during the outbreak of the COVID-19 pandemic. In practice we often come across different terms that can describe the parents' behavior towards the child, regardless of whether it is an educational attitude, educational style or parents' educational procedure. The style and parents' educational level, implies a consistent way of parents' behaviour, who establish a general relationship with the child (Ljubetić, 2007). It is emphasized that the parent must be consistent because he or she represents the appropriate measure and course of action that builds authority over the child and child's orientation. In fact, the style and level of education implies an emotional climate within which the action takes place between the parents - the child (Ljubetić, 2007). 
Educational styles are formed early and imply that the child adopts the parental behavior pattern and the parent perceives the child's reaction as a positive or negative support for their actions. Family education is the foundation of a child's personality development. To better understand the impact that parents have on the development of children, it is necessary to distinguish parents' educational styles. Parenting style can be defined as the totality of parental attitudes towards the child and the emotional climate around which different parenting procedures take place (ČudinaObradović and Obradović, 2003). Parenting styles vary in two dimensions. The first dimension is the warmth of the parents which means the amount of support, love and warmth that the family gives to the child. While parental control as the second dimension, represents the degree to which parents control the child and events that are part of his or her life (Berk, 2015). Regarding question "Do I do recreational sports activities?" the respondents do not distinguish between them because they used different spaces both before the COVID-19 pandemic period and during the quarantine in the COVID-19 period. During the COVID-19 pandemic period, respondents realized the importance of asking whether organizing sports and recreational activities would be beneficial, especially among respondents whose parents had a low level of education. In the question "Do you actively participate in any sports activities?" there was a fewer respondent whose parents had low school education, who answered "YES". During the COVID-19 pandemic period, respondents in both groups did not have access to sports activities.

In the frequency of cigarette consumption during a day the respondents were distinguished among themselves. Respondents whose parents had low education before the COVID-19 pandemic period had the highest daily cigarette consumption. During the COVID-19 pandemic period respondents from both groups had the largest number who did not smoke. Staying with a parent during quarantine has reduced the number of cases of those who have smoked cigarettes.

In the frequency of alcohol consumption during a day the respondents were distinguished among themselves before the COVID-19 period. Respondents whose parents had low schooling, during the COVID-19 pandemic period had the highest daily alcohol consumption. During the COVID-19 pandemic period respondents in both groups had the highest number who consumed alcohol. Perhaps staying with parents during the quarantine where alcohol was consumed has influenced the increase in the cases of those who have consumed alcohol.

In the frequency of drug use, the respondents did not distinguish before the COVID-19 period. During the COVID-19 pandemic period, respondents in both groups had smaller numbers who consumed the drug. Perhaps staying in quarantine with parents and the opportunity to come to possession of drugs has been impossible.

In food and meal habits respondents were distinguished from each other before the COVID-19 period. During the period of the COVID-19 pandemic the respondents of both groups had habits in equal food and meals.

In the time spent sleeping during 24 hours, the respondents with more hours of sleep turned out to be the respondents whose parents have low education before the COVID-19 period. 
During the COVID-19 pandemic period respondents in both groups had the largest number of hours spent sleeping.

\section{Conclusion}

The educational level of parents affects the lifestyle of children and is also influenced by numerous factors related to parents and children, as well as the closer and wider social, cultural and religious environment in which the family exists. Based on the preliminary data of the survey, there is a significant tendency towards an unhealthy lifestyle during the quarantine implemented by the COVID-19 pandemic. Compared to before, this is influenced by social and physical inactivity, poor quality of sleep, caused by forced confinement at home.

The spectrum of actions of parents and the general emotional atmosphere in which the child grows, affect the development of his personality, because this is where the identification takes place. Dangerous behaviors of children and young people like consuming alcohol and tobacco and experimenting with drugs are increasing from year to year. Research has shown that one of the risk factors for this is family. This longitudinal research conducted on a sample of high school students in Gjilan also showed the importance of parents' educational level in the lifestyle of their children before and during the COVID-19 pandemic.

\section{References}

Berk, L.E. (2015). Dječja razvojna psihologija. Jastrebarsko: Naklada Slap.

Čudina-Obradović, M., \& Obradović, J. (2006). Psihologija braka i obitelji, Zagreb:Golden Marketing - Tehnička knjiga.

Klarin, M. (2006). Razvoj djece u socijalnom kontekstu. Jastrebarsko: Naklada Slap.

Kopko, K. (2007). Parenting styles and adolescents. Cornell University Cooperative Extension.

Ljubetić, M. (2007). Biti kompetentan roditelj. Zagreb: Mali profesor, (monografija). https://www.bib.irb.hr/293828

Milutinović, J., Zuković, S., Klemenović, J. (2012). Pluralizam filozofija obrazovanja i vrednosti: obrazovanje za građansko društvo, U: R. Grandić (ur.) Pedagoški pluralizam i filozofija obrazovanja, 69-88. Novi Sad: Filozofski fakultet, Odsek za pedagogiju.

Raboteg-Šarić, Z., Sakoman, S., Brajša-Žganec, A. (2002). Stilovi roditeljskog odgoja, slobodno vrijeme i rizično ponašanje mladih. Društvena istraživanja: časopis za opća društvena pitanja, 11(2-3), 239-263.

Robertson, A., Lobstein, T., Knai, C. (2007). Obesity and socio-economic groups in Europe: evidence review and implications for action. Brussels: European Commission.

Elezi, A,. Rexhepi, Sh,. Georgiev, G., Elezi, G,. Myrtaj, N. (2016). Sports and level of depression in young sportsmen. Acta Kinesiologica, 10(2), 75-78. 